\title{
ECONOMIC CONDITIONS IN THE AREA AROUND THE SEA OF GALILEE IN PRE-HELLENISTIC TIMES
}

\author{
WOLFGANG ZWICKEL
}

Seminar für Altes Testament und Biblische Archäologie, FB 01: Evangelische Theologie, Johannes Gutenberg-Universität Mainz, 55099 Mainz, e-mail: zwickel@uni-mainz.de

Received: $11^{\text {th }}$ May 2017, Accepted: $15^{\text {th }}$ September 2017

\begin{abstract}
In a landscape archaeology project all the fertile fields around the Sea of Galilee (an area of $50 \times 30 \mathrm{~km}$ ) were mapped. The whole territory was subdivided in 5 regions: Jordan valley, Lower Galilee, Upper Galilee, Golan and Transjordanian Hill Country. Additionally all ancient sites from the Neolithic to the Persian period, which are mentioned in archaeological literature, were collected - all together more than 300 sites. These data allow a reconstruction of the economic conditions in antiquity in the area around the Sea of Galilee. Landscape archaeology clearly demonstrates that the economic basis may have been completely diverse in the five sub-regions, and also during different times. Agriculture played a major role in the economy of ancient people. During some periods and in some regions people lived in the midst of the fields, while in other periods they settled at the edges in order not to waste valuable farmland. On the other hand the position of some sites in some periods clearly demonstrates that trade played a major role for the income of the settlers, or basalt mining and working. Streets can be reconstructed, and our methodological approach allows new insights in the economy of this area
\end{abstract}

Keywords: Landscape archaeology, Israel, Sea of Galilee, economic conditions, settlements

For a long time archaeologists were only interested in excavating towns and villages. The surrounding area was not of interest. In the last decades researchers understood more and more that landscape is very important for a flourishing town. If the fertile lands around a city offer good opportunities for a specialization in a specific kind of agriculture (e.g. winegrowing, cultivation of olive trees, date-palms or grain), the town has the possibility of earning more money. The same is true for any other kind of industrial specialization like metal or stone working. If an important regional or international trade route bypasses the town, the products can easily be sold. Integrating the landscape surrounding of a town into research, considering its natural products and its geographical and geological conditions, helps archaeologists to understand daily life and the progress of a town much better.

My research project is not interested in the landscape around a specific town, but of a well-known natural area: the Sea of Galilee (Zwickel, 2017). The main aim of this study is to understand the region much better by using a landscape and settlement history approach. 
Around the Sea there is not only one, but there are five geographical units which are completely different one from each other (Fig. 1):

- the Golan

- the Transjordanian hill country

- the southern Jordan valley

- Lower Galilee and

- Upper Galilee.

Each of these areas also has its own historical development and its own culture. Considering regionalism is an important new aspect for Palestinian / Biblical archaeology. Normally scholars understand the Southern Levant as a corporate identity, but my research clearly demonstrates that there are many different developments even on such a limited territory as the area around the Sea of Galilee.

\section{Fig. 1: Geographical territories in the research area}

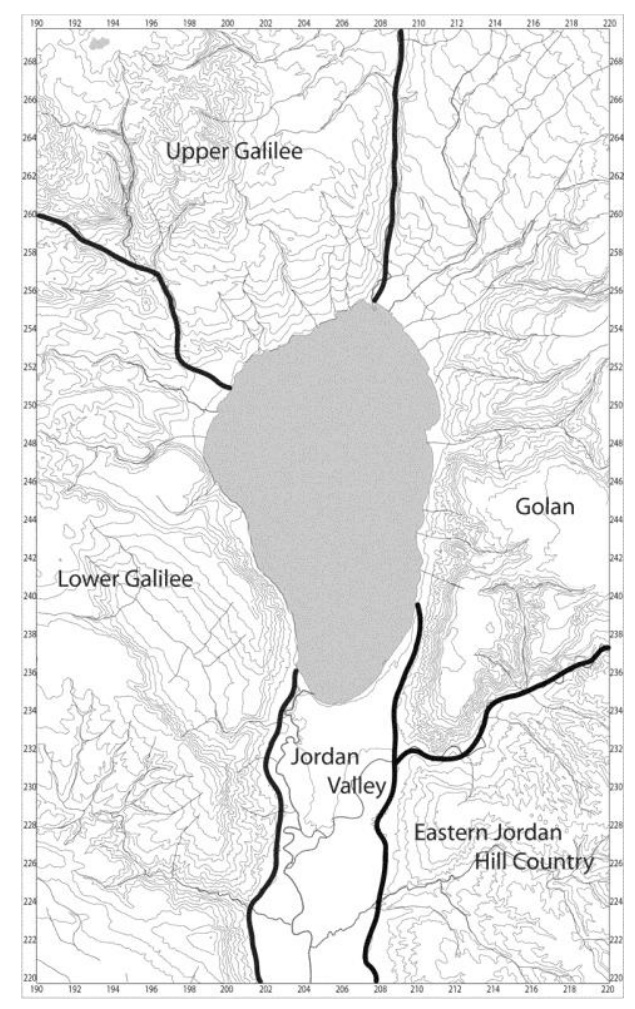

All together 470 pre-Hellenistic sites were noted (Fig. 2) which are mentioned in the scientific literature published in the last 100 years. 64 of these or $13.6 \%$ are at least partly excavated (Fig. 3) - a relatively reliable data source for reconstruction historical events in the area. 
Fig. 2: Distribution of sites with pre-Hellenistic archaeological material

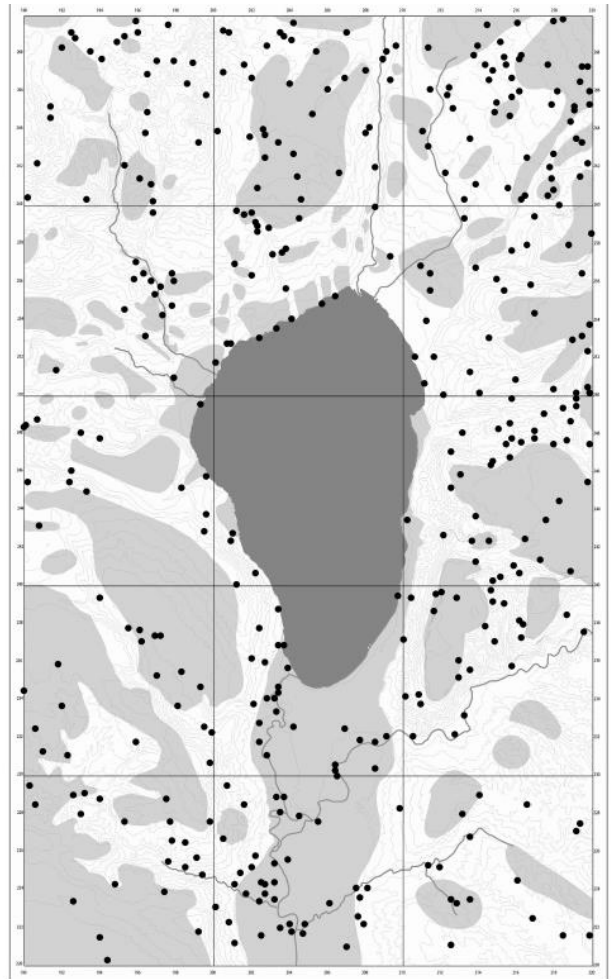

Fig. 3: Excavated sites in the research area

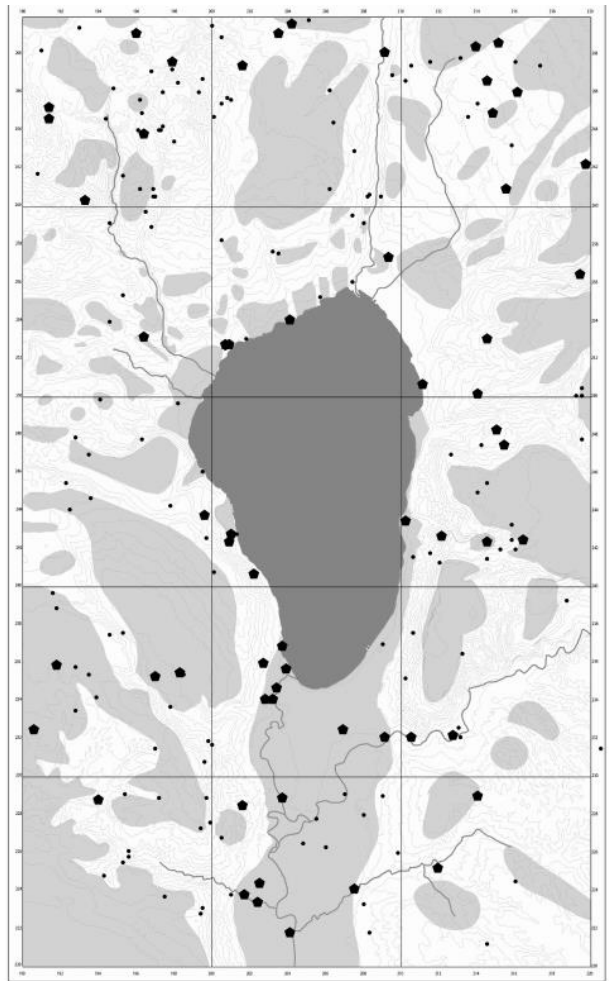

Permanent settlements (for only some decades or even for several hundreds of years) need some specific conditions:

There must be fertile fields around the settlements to produce enough nourishment for the inhabitants. We mapped all areas with fertile fields around the Sea of Galilee (shown on the figures in grey color). These fertile fields are a maximalist approach to agriculture. Certainly not all fields were used during every period. But sites situated either at the edges of the fertile fields or in the midst of the fields demonstrate agricultural activities.

- Upper Galilee and the Golan are rich in basalt. The distribution of sites may also demonstrate that basalt exploitation and working for household instruments (mill stones, bowls et cetera) distributed into different parts of the country was in some periods important for the income of the settlers.

- Without a good freshwater resource in the neighborhood no permanent settlement is possible. Therefore all water sources according to descriptions of the $19^{\text {th }}$ century were collected (Fig. 4).

- Trade routes are important to sell a surplus or to buy things which cannot be produced locally. Planting wheat, barley and emmer was mostly used for the personal use of the settlers. Only in good years a surplus can be traded. But the production of stone vessels and of olive oil normally results in a far-reaching exchange with other goods. We know the Roman-Byzantine road system (Fig. 5) rather well (Zwickel, 2017, 45-46; Roll, 2009), as we do for the road system in the 
Arab period (Zwickel, 2016). Fig. 6 presents possible road connections in the pre-Roman periods, based on the distribution of sites. The methodological idea behind this reconstruction of roads in antiquity is to combine settlements which are in a clear chain along traditional road systems (cf. Dorsey, 1991 and the Roman-Arab road systems) and situated outside of agricultural areas. Also sites situated directly at a river controlling a ford may be significant markers for ancients roads.

I only can present here some major results of my study and I want to start with some general remarks (for detailed data cf. the relevant chapters in Zwickel, 2017). During the Neolithic period (Fig. 7) a high number of sites is situated along the western shore of the Sea of Galilee and along the permanent rivers. This clearly demonstrates that hunting played a major role for the feeding of the people.

\section{Fig. 4: Fertile fields (grey) and water sources}

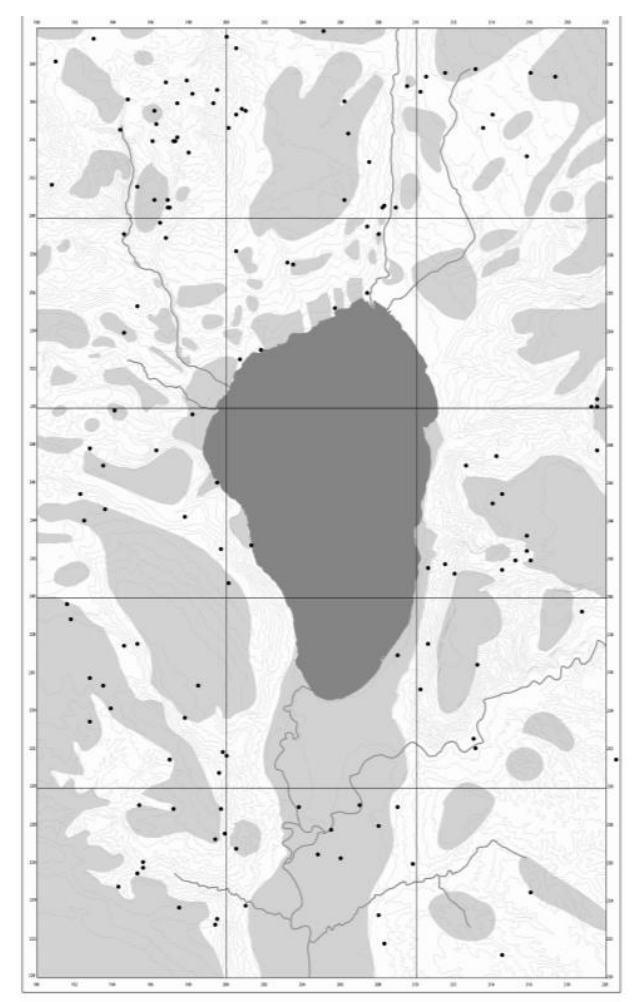


Fig. 5: Roman-Byzantine road system

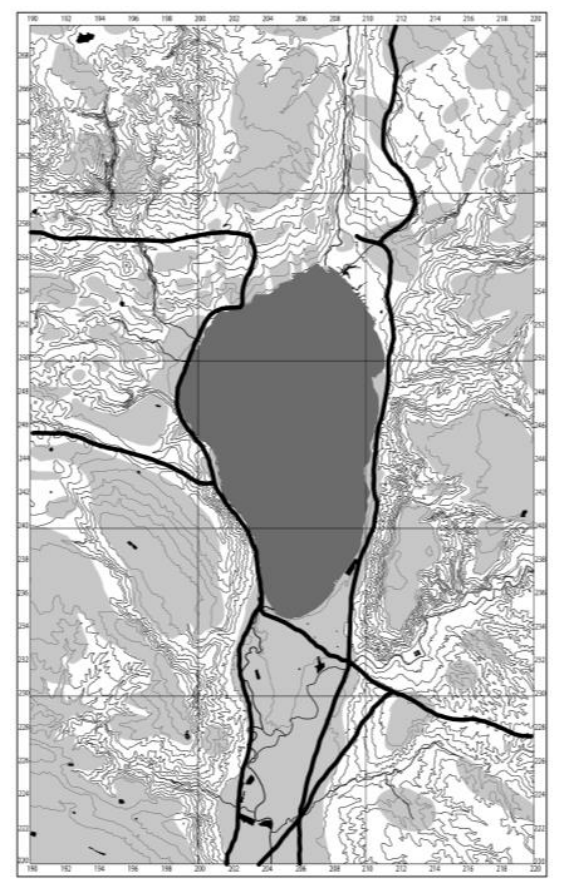

Fig. 6: Possible road connections in the research area

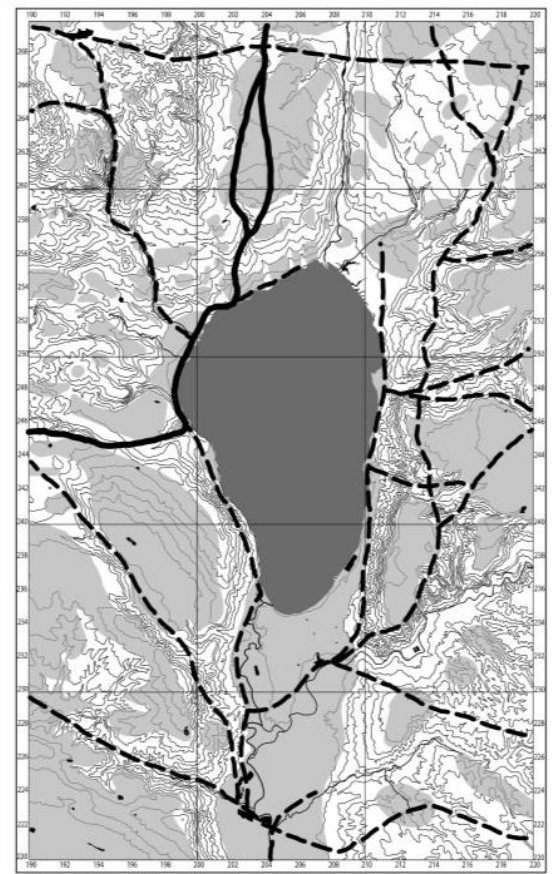

Fig. 7: Neolithic sites and reconstructed road system

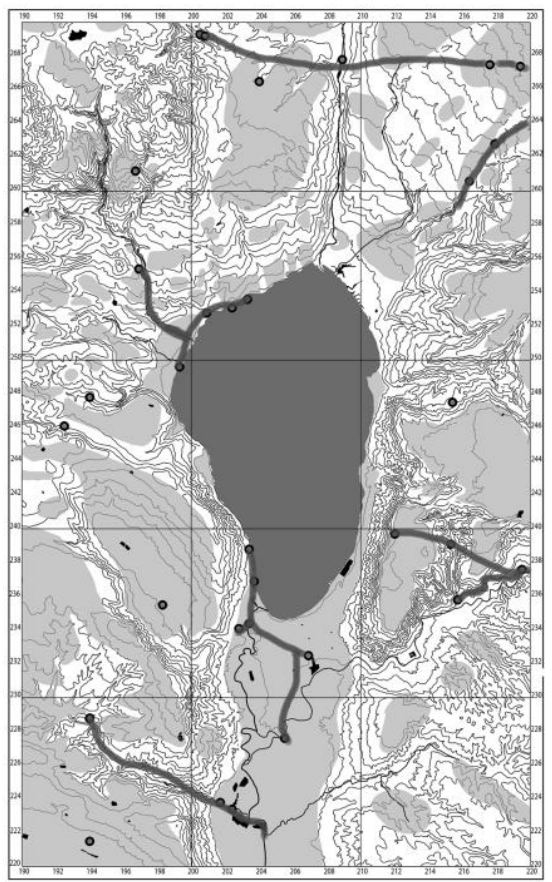


In the Chalcolithic period (Fig. 8) many sites existed in Upper Galilee north of the Sea of Galilee and in the central Golan. This is an area with plenty of basalt, and different basalt items, especially the famous pillar figurines, are typical for the Golanite Chalcolithic culture (Epstein, 1998, 229-267). Therefore we have to assume that working basalt played a major role in the economy of the people living there. Additionally excavations showed that oil industry was important for the economy of the people (Epstein, 1993).

Fig. 8: Chalcolithic sites and reconstructed road system

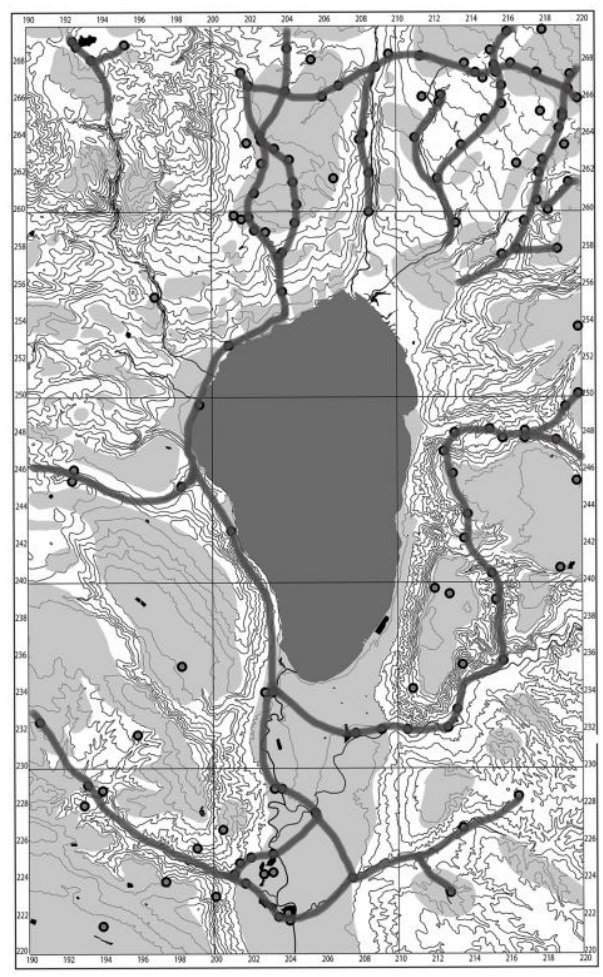

\section{Fig. 9: Early Bronze Age I sites and reconstructed road system}

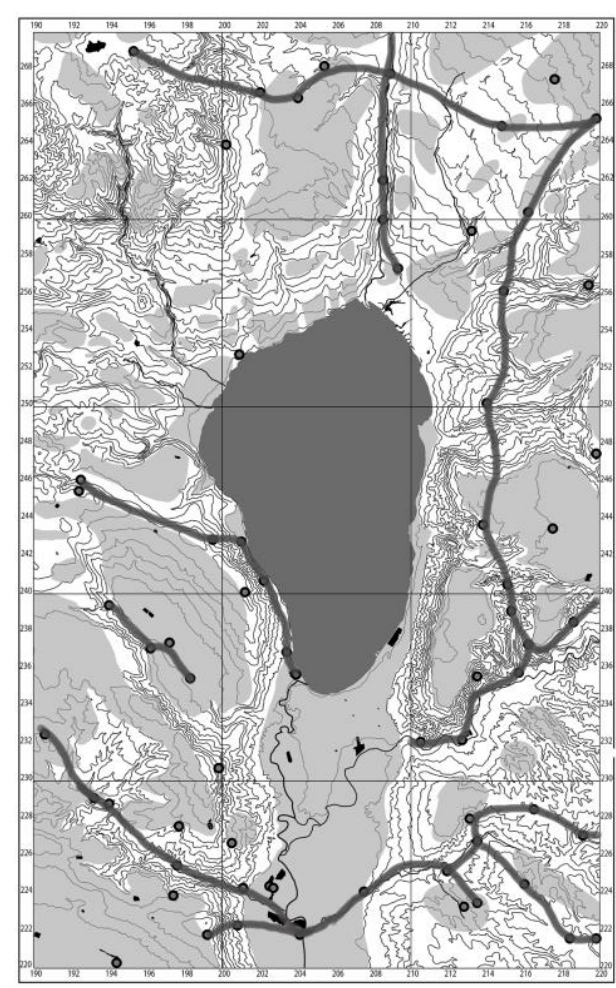

This changed completely during the Early Bronze Age I period (Fig. 9). Most of the sites are situated now along the edges of the fertile fields. Evidently no cultivable area was settled. Agriculture now took on the most important role for the income of the people. This was partly also true for the Early Bronze Age II (Fig. 10) and III (Fig. 11) period, although the number of sites decreased. 
Fig. 10: Early Bronze Age II sites and reconstructed road system

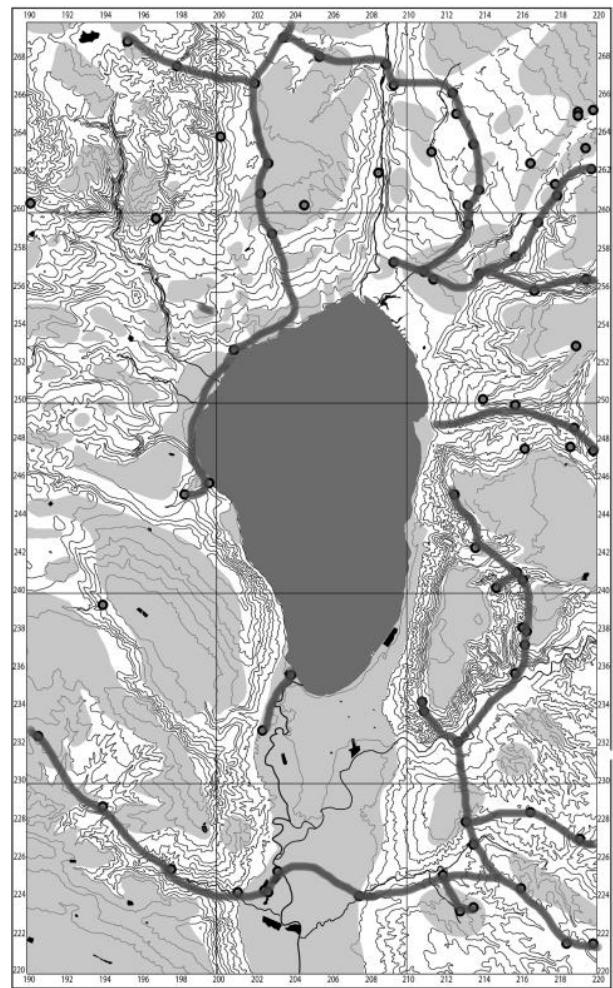

Fig. 11: Early Bronze Age III sites and reconstructed road system

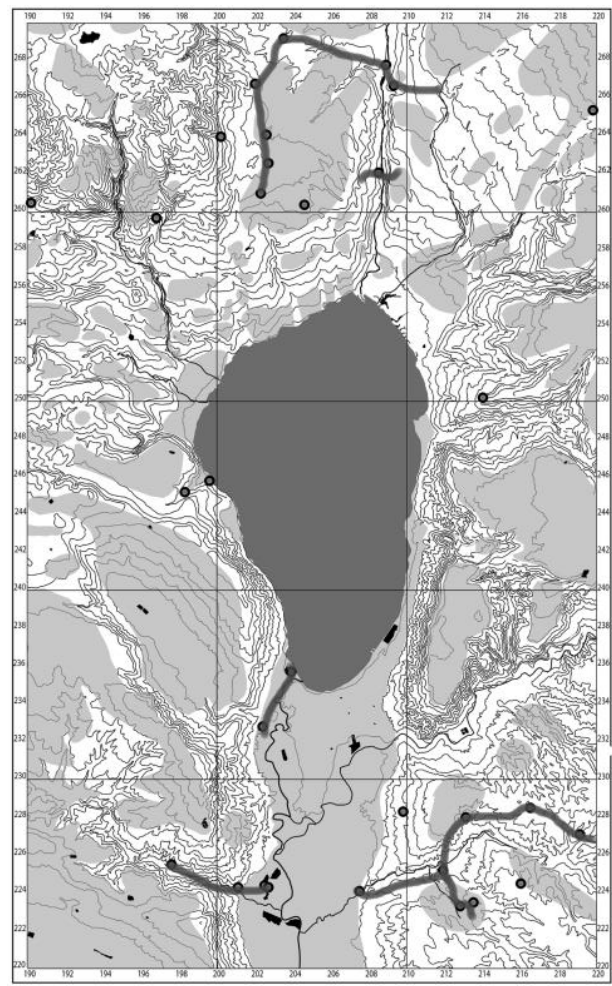

During the Early Bronze Age IV/Middle Bronze Age I period (Fig. 12), we have a completely different distribution of sites. Some are situated in the wadis, far away from any fertile field. We will discuss this later. Khirbet el-Kerak, the dominating town during Early Bronze Age II and III (Greenberg et al., 2012), got abandoned, and some former inhabitants settled now in the midst of the fields in the Jordan plain. For small communities consisting of one or two nuclear families it is much easier to live next to a fertile area. The daily way to the fields under cultivation was short. Evidently the political situation changed. During the Early Bronze Age I-III villages were safeguarded by a city wall or by steep slopes or a river. Now the political situation was likely much safer, and it was not necessary anymore to protect the property of the small communities by strong fortifications. Anyhow, larger communities with hundreds or even thousands of settlers still needed a shelter; in Khirbet el-Kerak the original course of the Jordan River offered such a shelter.

The situation completely changed once more during the Middle Bronze Age II period (Fig. 13; cf. also Maeir, 2010). No other period yielded so many sites in our research area as the Middle Bronze Age period. In the Jordan valley and in Lower Galilee agriculture still played a major role, but in Upper Galilee and the Golan many settlements are far away from fertile fields. Evidently basalt exploitation was reactivated, and Hazor - reaching metropolis size and status during this period - likely served as a center of basalt industry. Another insight is of specific importance for dating the end of the Middle Bronze Age II in this territory. Most of the sites mentioned in the topographical list of Thutmosis III were not settled in the Late Bronze Age, but only in the Middle Bronze Age II period. Therefore we 
have to assume that the Middle Bronze Age II lasted in northern Palestine until the year 1479 $\mathrm{BCE}$, and the campaign of Thutmosis III destroyed most of the settlements there.

Fig. 12: Early Bronze Age IV/Middle Bronze Age I sites and reconstructed road system

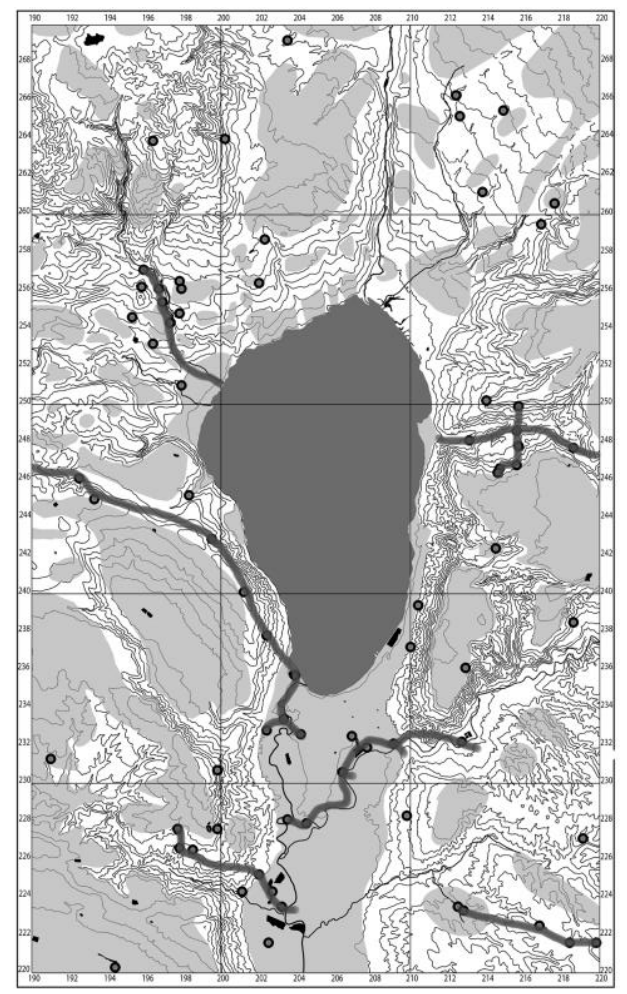
Fig. 13: Middle Bronze Age II sites
and reconstructed road system

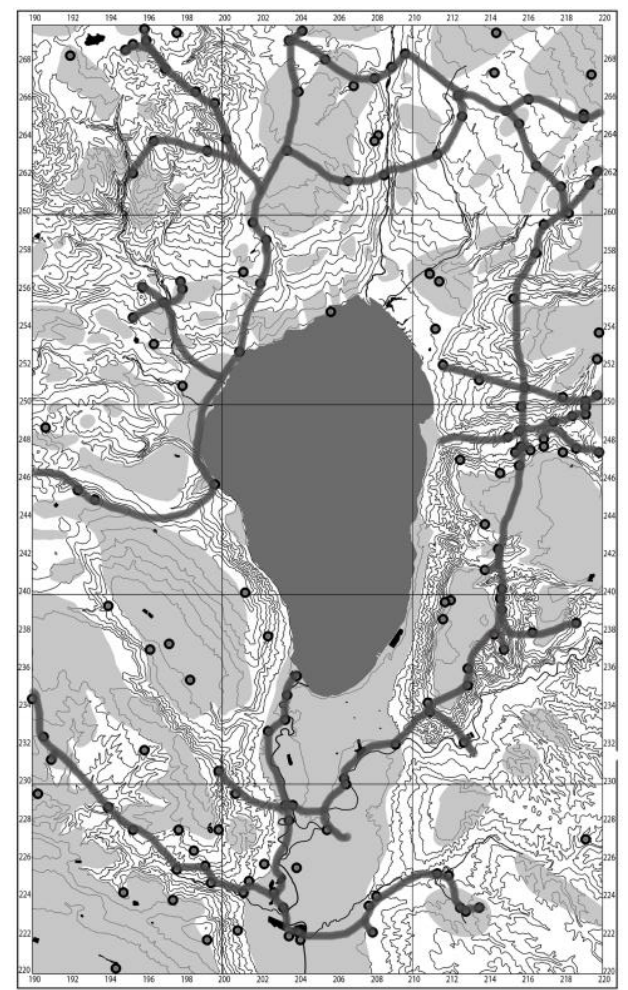

Late Bronze Age I (Fig. 14) and II (Fig. 15) is characterized by a heavy decline of settlement density. Sites situated next to fertile fields were mostly abandoned, and the via maris lost its importance as international trade route, as we will see later. The new center for northern Palestine became Beth-Shan, which is a little bit south of my research area (Mazar, Ed. 2006; Mazar \& Mullins, Eds. 2007).

Iron Age I (Fig. 16) is a period of resettlement, especially in Lower and Upper Galilee. Some Late Bronze Age sites evidently were the nucleus for new settlement activities. Agriculture played a major role again for the income of the people, but in Upper Galilee and in the Golan basalt working industry was reset.

The Iron Age II period (Fig. 17) is a timespan of stabilization. Compared to Iron Age I the number of sites increased, but the distribution of these sites is nearly the same. In $733 \mathrm{BCE}$ the whole area was destroyed, and only few sites survived (Gal, 1998; Gal, 2009). 
Fig. 14: Late Bronze Age I sites and reconstructed road system

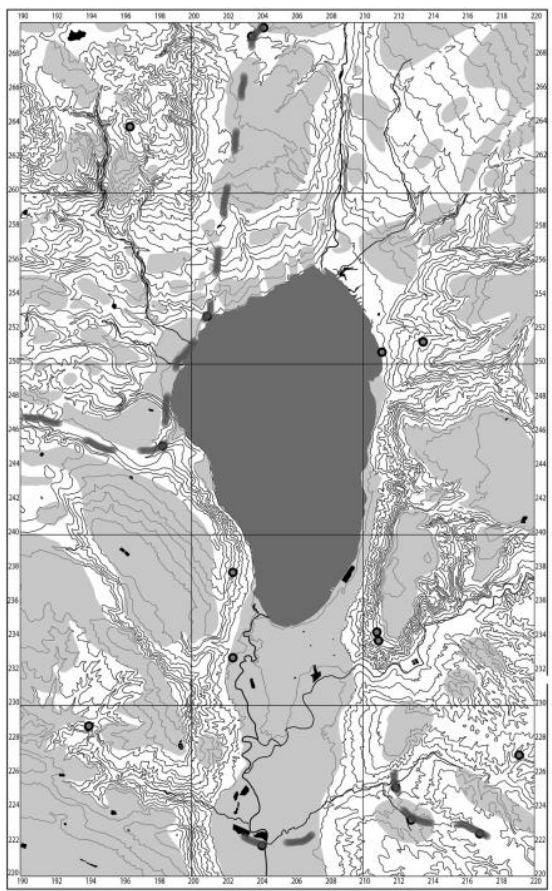

Fig. 16: Iron Age I sites and reconstructed road system

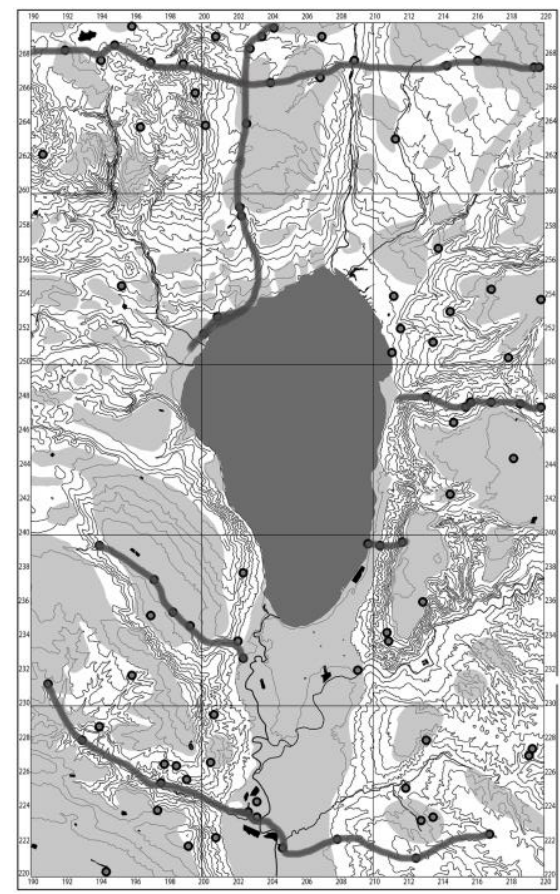

Fig. 15: Late Bronze Age II sites and reconstructed road system

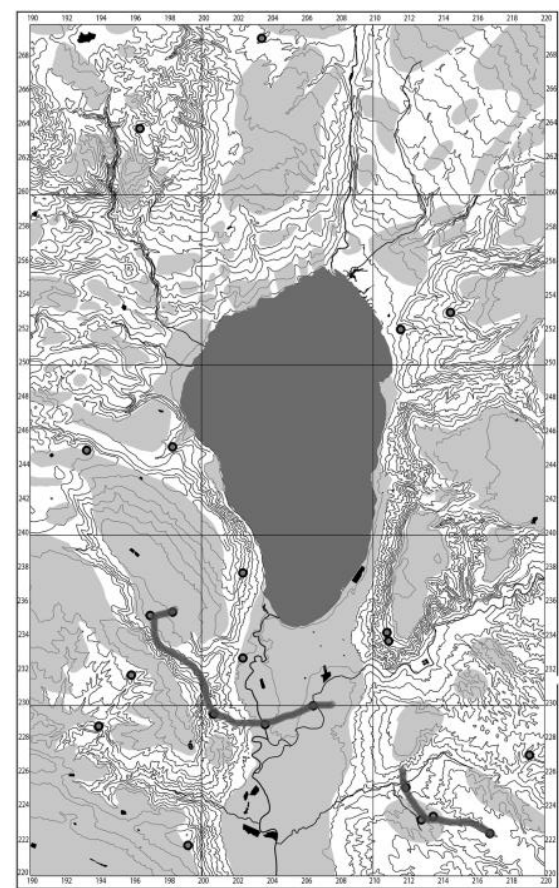

Fig. 17: Iron Age II sites and reconstructed road system

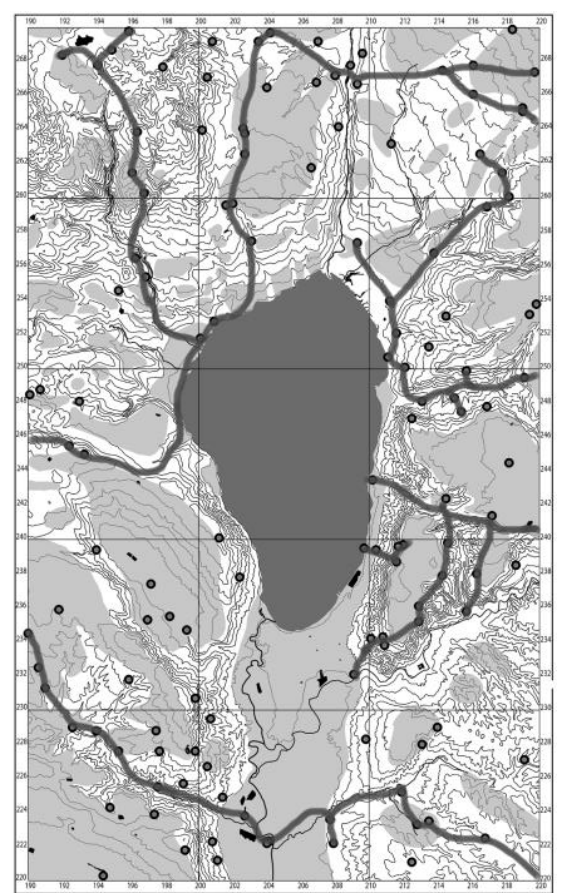


For the Persian period (Fig. 18) settlements are only scantily attested. Most of the mapped sites were not permanently settled or have only limited proof of settlement activity. We know of the existence of two Assyrian and Persian governor residences in this area, one in Ayyelet ha-Shahar (Kletter \& Zwickel, 2006), the other one in Kinneret/Tell el-Oreme (Fritz, 1990, 99-109). Some sites surrounding these two residences were likely settled by people supporting the elites of the palaces with nourishment. A third residency likely existed in the south near Tel Rekesh, where another cluster of small sites existed.

\section{Fig. 18: Persian period sites and reconstructed road system}

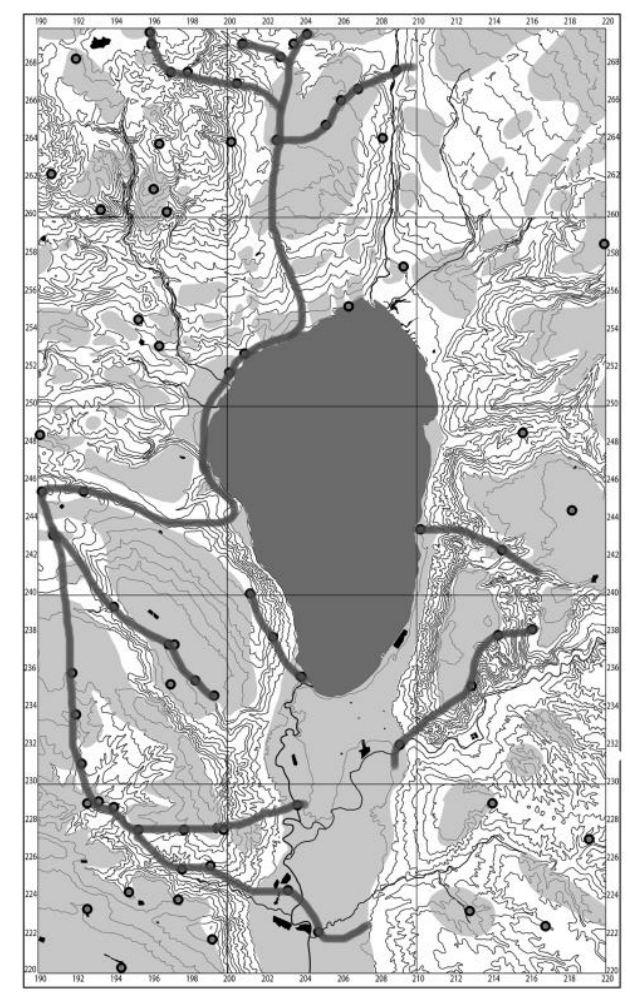

In a second part I want to mention a topic which is not the center of my book (Zwickel, 2019): the change of road connections from the Neolithic to the Persian period.

The general layout of sites offers some data about the routes which were used in antiquity. But did people always use the same roads over 10,000 years, and why did they change the road system?

During the Neolithic period (Fig. 7) no far reaching trade connections can be observed. Some sites are situated at fords crossing the Jordan River or some other smaller rivers. But evidently no major well established trade connections existed there. Trade was limited to small regional areas.

The situation changed completely during the Chalcolithic period (Fig. 8). Now several road systems existed, demonstrating important trade connections. Likely the via maris was already in use during this period. We have trade connections in nearly all wadis connecting not only the Huleh valley with the Sea of Galilee but also the western Lower Galilean territories and the heights in the Golan with the Sea. This is not surprising, because we 
already observed that basalt working and oil production played a major role during the Chalcolithic period.

Although we have less sites during the Early Bronze Age I period (Fig. 9), the main road connections are nearly the same. Only the via maris apparently lost its importance as an international trade route. Based on a much smaller density of settlements people were not interested in international trade connections anymore but more in regional trade.

During Early Bronze Age II (Fig. 10) the via maris became important again. Significant changes can be observed in the Golan area. During the Early Bronze Age I period there is a north-south road on the eastern side of the Sea of Galilee. During Early Bronze Age II we have road connections from the Sea of Galilee up to the fertile areas east of our research area. The direction of the trade evidently changed. Likely agricultural goods from the Golan were transferred to the area of the Sea.

During Early Bronze Age III (Fig. 11) the well-established road system broke down. Some regional roads can be observed in the Upper Galilee and in the Jordan valley. Also during Early Bronze Age IV/Middle Bronze Age I (Fig. 12) the road system was regionally, although some more, but generally rather small sites existed around the Sea of Galilee.

There is a significant change of the road system during the Middle Bronze Age II period (Fig. 13). Now the via maris was revitalized, but also plenty of small roads existed in the whole area. There were roads from the Sea to the eastern part with the fertile fields east of our research area, but also all the wadis in the west of the Sea were used for road connections. Regional and international trade must have played a major role for the income of the people.

With the destruction of many Galilean sites by Thutmosis III in 1479 BCE the international trade in our research area completely broke down. We only can assume that at least during the Late Bronze Age I period (Fig. 14) some activities still existed on the via maris, but nearly all service points along this road disappeared. While a small site in Nahal Raqqat survived, Kinneret/Tell el-Oreme was abandoned during the Late Bronze Age II (Fig. 15). Since Hazor was also in the Late Bronze Age an important urban center (Ben-Tor 2016) with contacts to Mesopotamia (Horowitz/Oshima 2006), likely some traders still used the via maris. But trading became unsafe because no accommodations existed anymore south of Hazor. Instead of the via maris Seti I (1290-1279 BCE) and Ramesses II (1290-1279 BCE) established a new road which is known from some Egyptian stelae found in Jordan and southern Syria (Wimmer 2002; Wimmer 2008, Zwickel in press). This road crossed the Jordan River between Beth-Shan and Pella and continued to the north, bypassing ancient Damascus and reaching the Euphrates River anywhere near Deir ez-Zor or Mari. Using this new road had some advantages for the traders. While the Beqa ${ }^{c}$ valley was disputed by Hittite and Egyptian troops and trading was therefore dangerous, the new road passed through rather peaceful territory. The decrease of trade along the traditional road had important consequences especially for the prominent site of Hazor, which was not able to survive anymore. Hazor lost all its settlers during the Late Bronze Age II period and came to a final end around $1230 \mathrm{BCE}$ (Ben-Tor 2016, 113-118) because of the enormous retrogression of trade activities. If the nearly deserted town of Hazor was finally conquered by Habiru troops or by Proto-Israelites or by any other group becomes less important. More important is that the decline of trading activities was responsible for the final end of Hazor.

The Iron Age I period (Fig. 16) is characterized by several new settlements. But all the road connections seem to be rather regional. In any case there is a characteristic no-mans-land more than $10 \mathrm{~km}$ broad south of Kinneret/Tell el-Oreme. The simplest explanation is that the territory north of Kinneret/Tell el-Oreme originally belonged to Beth-Maacah with its capital Abel-Beth-Maacah, while the settlements in Lower Galilee belonged to Naphtali. There existed two roads in Beth-Maacah: one from north (Abel-Beth-Maacah) to south 
(Kinneret/Tell el-Oreme), and another one from west, likely from the Mediterranean shore to the east (Golan). Also in Naphtali the road system is east-west oriented. While there was evidently no intensive contact between Beth-Maacah and Naphtali, exchange between eastern and western territories existed.

During Iron Age II (Fig. 17) the territory north of Kinneret/Tell el-Oreme was integrated into the Israelite kingdom. But east of the Huleh valley and the Sea of Galilee the kingdom of Geshur and later the kingdom of Aram-Damascus was established. Likely the road connections along the via maris were re-established during Iron Age II. This was important for the Israelite infrastructure being dependent again on international trade activities (cf. Schipper, 1999). South of the Sea of Galilee a road still connected Lower Galilee with the Transjordanian hill country. This may demonstrate close political contacts between the tribes of Naphtali, Issachar and eastern Manasse. Also in the Golan area some regional roads existed, likely for trading basalt items.

The reconstruction of the road system during the Persian period (Fig. 18) is hard to establish. Many sites were not permanently settled. But evidently a rather dense system of regional roads existed, although they were not intensively used. The via maris bypassed the Assyrian governer's residencies in Dan (Thareani, 2016), Ayyelet ha-Shahar and Kinneret which were still in use during the Persian period.

Landscape archaeology allows to reconstruct some historical outlines which cannot be observed by excavations on important sites alone. It allows a reconstruction of historical developments and can explain the reasons for the changing situation over a period of thousands of years. It even may explain long debated problems like the final destruction of the prominent site of Hazor.

\section{REFERENCES}

Ben-Tor, A. (2016). Hazor. Canaanite Metropolis, Israelite City. "The Head of All Those Kingdoms" (Joshua 11:10), Jerusalem: Israel Exploration Society/Biblical Archaelogy Society.

Dorsey, D.A. (1991). The Roads and Highways of Ancient Israel, Baltimore/London: John Hopkins University Press.

Epstein, C. (1993). Oil Production in the Golan Heights during the Chalcolithic Period, Tel Aviv 20, 133-146.

Epstein, C. (1998) The Chalcolithic Culture of the Golan (Isarael Antiquities Authority Reports 4), Jerusalem: Israel Antiquities Authority.

Fritz, V. (1990). Kinneret: Ergebnisse der Ausgrabugnen auf dem Tell el- Orēme am See Gennesaret, 1982-1985 (Abhandlungen des Deutschen Palästina-Vereins 15), Wiesbaden: Harrassowitz.

Gal, Z. (1998). Israel in Exile, Biblical Archaeology Review 24:3, 48-53.

Gal, Z. (2009). The Lower Galilee between Tiglath-Pileser III and the Beginning of the Persian Period, Eretz Israel 29, 77-81 (ivrit). 284*-285* (English summary).

Greenberg, R. et al. (2012). Tel Bet Yerah: Hub of the Early Bronze Age Levant, Near Eastern Archaeologist 75, 88-107.

Horowitz, W. \& Oshima, T. (2006). Cuneiform in Canaan. Cuneiform Sources from the Land of Israel in Ancient Times, Jerusalem: Israel Exploration Society/Hebrew University of Jerusalem. 
Kletter, R. \& Zwickel, W. (2006). The Assyrian Building of Ayyelet ha-Shahar, Zeitschrift des Deutschen Palästina-Vereins 122, 151-186.

Maeir, A. (2010). In the Midst of the Jordan. The Jordan Valley during the Middle Bronze Age (circa 2000-1550 BCE). Archaeological and Historical Correlates (Österreichische Akademie der WIssenschaften. Denkschriften der Gesamtakademie LXIV/Contributions to the Chronology of Eastern Mediterranean XXVI), Wien: Österreichische Akademie der Wissenschaften.

Mazar, A. Ed. (2006). Excavations at Tel Beth-Shan 1989-1996. Volume I: From the Late Bronze Age IIB to the Medieval Period, Jerusalem: Israel Exploration Society/The Hebrew University of Jerusalem.

Mazar, A., Mullins, R. Eds. (2007). Excavations at Tel Beth-Shan 1989-1996. Volume II: The Middle and Late Bronze Age Strata in Area R, Jerusalem: Israel Exploration Society/The Hebrew University of Jerusalem.

Roll, I. (2009). Between Damascus and Megiddo: Roads and Transportation in Antiquity across the Northeastern Approaches to the Holy Land, in: Di Segni, L. et al. Ed., Man near a Roman Arch. Studies presented to Prof. Yoram Tsafrir, Jerusalem: Israel Exploration Society, 1*-20*.

Schipper, B. (1999). Israel und Ägypten in der Königszeit. Die kulturellen Kontakte von Salomo bis zum Fall Jerusalems (Orbis Biblicus et Orientalis 170), Fribourg/Göttingen: Universitätsverlag/Vandenhoeck \& Ruprecht.

Thareani, Y. (2016). Imperializing the province: a residence of a Neo-Assyrian City Governor at Tel Dan, Levant 48, 254-283.

Wimmer, St. (2002). A New Stela of Ramesses II in Jordan in the Context of Egyptian Royal Stelae in the Levant (unpublished lecture at ICAANE 3 in Paris).

Wimmer, St. (2008). Von Nubien bis Syrien: zur ramessidischen Stele von Tell eš-Šihâb, In: Adro, F, et al. Eds. Altägyptische Weltsichten (pp. 190-196). Akten des Symposiums zur historischen Topographie und Toponymie Altägyptens vom 12.-14. Mai 2006 (Ägypten und Altes Testament 68), Wiesbaden: Harrassowitz.

Zwickel, W. (2016). The Sea of Galilee in Islamic Times: The Geographical Conditions, In: Kuhnen, H-P. Ed. Khirbet al-Minya: Der Ummayyadenpalast am See Gennezareth (pp. 85-109) (Orien-Archäologie 36), Rahden: Marie Leidorf,.

Zwickel, W. (2017). Settlement History around the Sea of Galilee from the Neolithic to the Persian Period (Ägypten und Altes Testament 86), Münster: Ugarit-Verlag.

Zwickel, W. (in press), Late Bronze Age in the Northern Jordan Valley (to be published in a Festschrift in the series Ägypten und Altes Testament). 